\title{
A review of catalyst and multifunctional reactor development for sustainable biodiesel production
}

\author{
Narita Chanthon $^{\mathrm{a}}$, Kanokwan Ngaosuwan ${ }^{\mathrm{b}}$, Worapon Kiatkittipong ${ }^{\mathrm{c}}$, Doonyapong Wongsawaeng ${ }^{\mathrm{d}}$, \\ Weerinda Appamana ${ }^{\mathrm{e}}$, Suttichai Assabumrungrat ${ }^{\mathrm{a}, \mathrm{f}, \mathrm{*}}$ \\ a Center of Excellence on Catalysis and Catalytic Reaction Engineering, Department of Engineering, \\ Faculty of Engineering, Chulalongkorn University, Bangkok 10330 Thailand \\ b Chemical Engineering Division, Department of Engineering, Rajamangala University of Technology \\ Krungthep, Bangkok 10120 Thailand \\ c Department of Chemical Engineering, Faculty of Engineering and Industrial Technology, Silpakorn \\ University, Nakhon Pathom 73000 Thailand \\ d Research Unit on Plasma Technology for High-Performance Materials Development, Department of \\ Nuclear Engineering, Faculty of Engineering, Chulalongkorn University, Bangkok 10330 Thailand \\ e Department of Chemical Engineering, Faculty of Engineering, Rajamangala University of Technology \\ Thanyaburi, Pathum Thani 12110 Thailand \\ ${ }^{f}$ Bio-Circular-Green-economy Technology \& Engineering Center, BCGeTEC, Department of Chemical \\ Engineering, Faculty of Engineering, Chulalongkorn University, Bangkok 10330 Thailand
}

*Corresponding author, e-mail: Suttichai.a@chula.ac.th

Received 17 Aug 2021

Accepted 24 Aug 2021

ABSTRACT: Biodiesel is an alternative green fuel commonly used worldwide. The biodiesel production process consists mainly of production and purification steps. In the production step, there are two main reactions, transesterification and esterification, that require novel catalysts to achieve high yield in a short processing time; however, the immiscibility of the reactants limits the mass transfer and consequently the reaction rate. This article reviews the development of various catalysts: acid, base, and bifunctional catalysts, for transesterification and esterification. In addition, some interesting multifunctional reactors to improve biodiesel production are briefly discussed. A functionalized acid/base catalyst on a metal oxide support is a potential catalyst for transesterification/esterification. Moreover, an ultrasound-assisted reactor is a promising multifunctional reactor to be used in batch or continuous operation for biodiesel production with both homogeneous and heterogeneous catalysts.

KEYWORDS: biodiesel, transesterification, novel catalyst, process intensification

\section{INTRODUCTION}

Biodiesel is an alternative fuel that could be produced from various natural feedstocks including edible and non-edible oil, animal fat, and waste cooking oil (WCO). It is considered an environmentally friendly fuel because of carbon-neutrality, renewability, and biodegradability $[1,2]$. The two main reactions in biodiesel production are transesterification and esterification. Transesterification is a reaction between triglyceride (TG) and methanol in the presence of an acid, base, or enzyme catalyst, and three moles of fatty acid methyl esters (FAME) and one mole of glycerol were obtained; while esterification is a reaction between carboxylic acid, a free fatty acid (FFA), and methanol, and the products are one mole of ester and one mole of water [3]. The major problems in biodiesel production are due to the reversibility of both the transesterification and the esterification reactions and the immiscibility of oil and alcohol, resulting in poor mass transfer and consequently slow reaction rate. A homogeneous catalyst is a conventional choice for use in the process, but purifying biodiesel and recovering catalyst from the reaction mixture are difficult. This review focuses on recent developments of various catalysts for biodiesel production. Additionally, it provides the development of some promising multifunctional reactors for sustainable biodiesel production.

\section{CATALYSTS FOR BIODIESEL PRODUCTION}

There are 4 types of catalysts for biodiesel production: acid catalyst, base catalyst, biocatalyst, and bifunctional catalyst (Fig. 1). In this review, the 


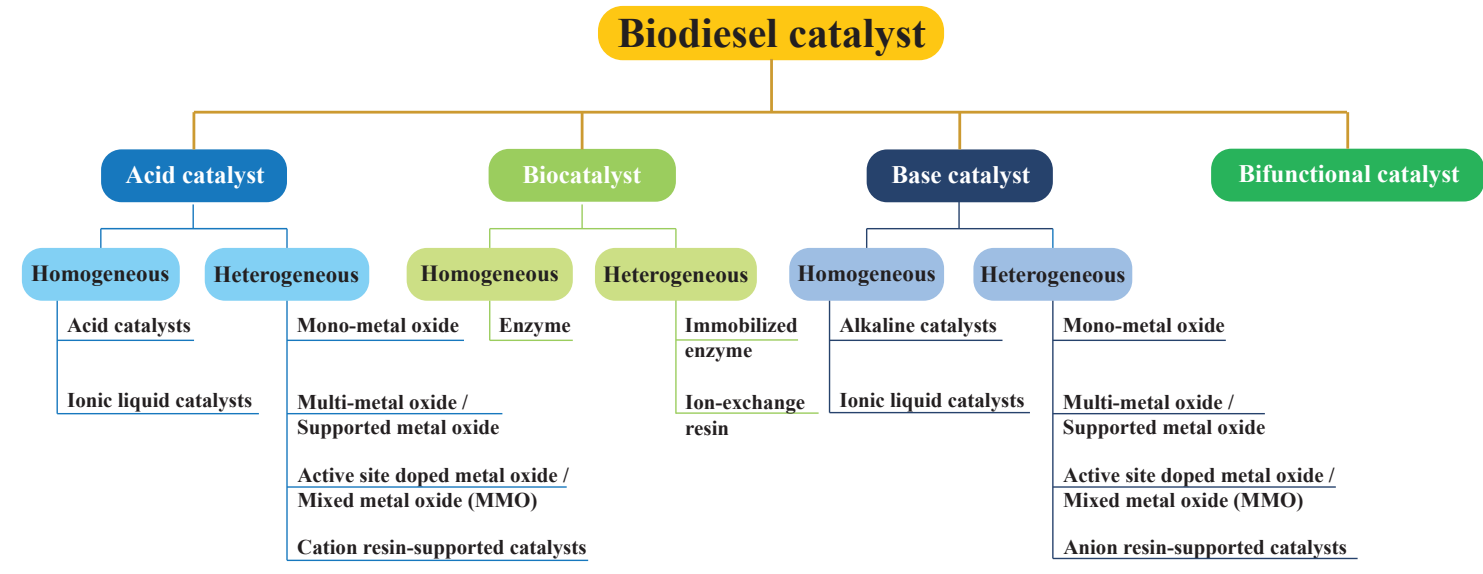

Fig. 1 Classification of catalysts for biodiesel production.

Table 1 Various homogeneous acid catalysts for esterification and their optimal conditions.

\begin{tabular}{|c|c|c|c|c|c|c|c|c|}
\hline Feedstock & Catalyst & $\begin{array}{c}\text { Catalyst loading } \\
\text { (wt.\%) }\end{array}$ & $\begin{array}{l}\text { Type of } \\
\text { alcohol }\end{array}$ & $\begin{array}{l}\mathrm{A} / \mathrm{O} \text { molar } \\
\text { ratio }\end{array}$ & $\begin{array}{c}\mathrm{T} \\
\left({ }^{\circ} \mathrm{C}\right)\end{array}$ & $\begin{array}{l}\text { Time } \\
\text { (h) }\end{array}$ & $\begin{array}{c}\text { Oil conversion } \\
(\%)\end{array}$ & Ref. \\
\hline Soybean oil & $\mathrm{H}_{2} \mathrm{SO}_{4}$ & 3 & Ethanol & $6: 1$ & 75 & 48 & 95.8 & [4] \\
\hline Soybean oil & $\mathrm{H}_{2}^{2} \mathrm{SO}_{4}^{4}$ & 3 & Methanol & $6: 1$ & 60 & 48 & 87.8 & [4] \\
\hline Soybean oil & $\mathrm{CF}_{3}^{2} \mathrm{COOH}$ & $2.0 \mathrm{M}$ & Methanol & $20: 1$ & 120 & 5 & 98.4 & [5] \\
\hline Stearic acid & $\mathrm{AlCl}_{3}$ & 5 & Methanol & $24: 1$ & 110 & 18 & 98.0 & [6] \\
\hline Palm kernel oil (PKO) & glacial $\mathrm{CH}_{3} \mathrm{COOH}$ & 15 vol. $\%$ & Methanol & $15: 1$ & 60 & 0.5 & 98.0 & {$[7]$} \\
\hline
\end{tabular}

A/O molar ratio: alcohol to oil molar ratio; T: temperature.

biocatalyst is not included because of its relatively high cost in comparison to chemical catalysts.

\section{Biodiesel production using acid catalysts}

Acid catalyst is a favorable choice for esterification because of its insensitivity to moisture and FFA; and, therefore, it is used for the pretreatment step of feedstocks containing high FFA before transesterification. However, corrosion presents a main drawback of the acid catalyst, resulting in corrosion and damage of equipment necessitating a special construction material. Although the catalytic activity via transesterification using an acid catalyst is lower than that of a base catalyst, the acid catalyst is still the selection priority of catalyst for biodiesel production due to its ability to use high FFA-oil feedstocks.

\section{Homogeneous catalyst}

Acid catalyst: A homogeneous catalyst is present in the same phase as the reactants resulting in a greater performance of biodiesel production compared with a heterogeneous catalyst.

Homogeneous acid-catalyzed esterification is a pretreatment reaction for biodiesel production from high FFA oil [8]. Since the catalytic activity via transesterification of an acid catalyst is about 4000 times lower than that of a base catalyst, the operation requires a higher temperature and a longer period of time for the reaction. However, any reaction temperature higher than the boiling point of alcohol is unfavorable due to the change of reaction from the liquid phase to the gas-liquid phase resulting in lower production efficiency. Canakci [4] studied the effect of alcohol types on biodiesel yield and found that using longer-chain alcohol required a higher reaction temperature caused by the steric hindrance effect. Table 1 summarizes various homogeneous acid catalysts for esterification. A strong acid, such as sulfuric acid $\left(\mathrm{H}_{2} \mathrm{SO}_{4}\right)$, is a common homogeneous acid catalyst; while a strong Lewis acid catalyst, such as aluminum chloride $\left(\mathrm{AlCl}_{3}\right)$ 
Table 2 Various acid IL catalysts for transesterification and their optimal conditions.

\begin{tabular}{|c|c|c|c|c|c|c|c|}
\hline Feedstock & Type of ionic liquid & $\begin{array}{l}\text { Type of } \\
\text { alcohol }\end{array}$ & Alcohol:oil molar ratio:ionic liq & $\begin{array}{c}\mathrm{T} \\
\left({ }^{\circ} \mathrm{C}\right)\end{array}$ & $\begin{array}{l}\text { Time } \\
\text { (h) }\end{array}$ & $\begin{array}{c}\text { Ester } \\
\text { yield (\%) }\end{array}$ & Ref. \\
\hline Soapberry oil & $\begin{array}{c}{[\mathrm{Ps}-\mathrm{MTH}]\left[\mathrm{CF}_{3} \mathrm{SO}_{3}\right]-\mathrm{FeCl}_{3}} \\
(\mathrm{x}=0.65)\end{array}$ & Methanol & 27.96:1:3.06 mmol & 127 & 8 & 97.04 & [9] \\
\hline Palm oil & {$\left[\mathrm{HSO}_{3}-\mathrm{BMIM}\right] \mathrm{HSO}_{4}$} & Methanol & $\begin{array}{c}\text { 11:1: } 9.17 \text { wt.\% } \\
\text { (wt.\%, based on lipids) }\end{array}$ & 108 & 6.43 & 98.93 & {$[10]$} \\
\hline Soybean oil & $\mathrm{PSH} / \mathrm{UiO}-66-\mathrm{NO}_{2}$ & Methanol & $\begin{array}{c}25: 1: 4 \text { wt. } \% \\
\text { (wt.\%, based on lipids) }\end{array}$ & 70 & 4 & 97.57 & {$[11]$} \\
\hline
\end{tabular}

$\mathrm{T}$ : temperature.

and zinc chloride $\left(\mathrm{ZnCl}_{2}\right)$, is an essential alternative catalyst [6]. Moreover, using tetrahydrofuran (THF) as a co-solvent with the $\mathrm{AlCl}_{3}$ catalyst can decrease the mass transfer limitation and, therefore, increase the biodiesel yield [6].

Ionic liquid catalyst: Ionic liquid (IL) could be an interesting catalyst for industrial-scale biodiesel production because of its high thermal stability and good miscibility. Besides, it can be designed as an acid (cation) or base (anion) IL.

Table 2 summarizes various acid IL catalysts and the influence of reaction conditions on the ester yield. The high catalytic activity of IL comes from its main component, the sulfonic functional group, contributing to increases in acid properties of the catalyst. Furthermore, Cai [9] found that adding metal chloride on IL gives a positive effect on the catalytic activity because it possesses Lewis and Brønsted acidity. Additionally, [Ps-MTH] $\left[\mathrm{CF}_{3} \mathrm{SO}_{3}\right]-$ $\mathrm{FeCl}_{3}(\mathrm{x}=0.65)$ expressed a good reusability as the biodiesel yield only decreased from $97.04 \%$ to $93.59 \%$ after five consecutive uses [9]. The biodiesel production using IL showed a greater performance compared with other catalysts; however, the expensive cost of IL catalysts can be a limitation for large-scale biodiesel production.

\section{Heterogeneous catalyst}

A heterogeneous catalyst appears in a different phase from the reaction mixture, and it can be easily separated and recovered. Heterogeneous acid catalysts can be classified into 4 types: mono-metal oxide, multi-metal oxide/supported metal oxide, active site doped metal oxide/mixed metal oxide (MMO), and cation resin supported catalysts.

Mono-metal oxide: Mono-metal oxide is a fundamental solid acid catalyst mostly prepared by soaking metal oxide powder in a sulfuric acid $\left(\mathrm{H}_{2} \mathrm{SO}_{4}\right)$ solution followed by calcination of the resulting solid to obtain a metal oxide acid catalyst. Some metal oxide acid catalysts are shown in Table 3. Sulfated zirconia $\left(\mathrm{SO}_{4}^{2-} / \mathrm{ZrO}_{2}\right)$, sulfated tin oxide $\left(\mathrm{SO}_{4}^{2-} / \mathrm{SnO}_{2}\right)$, and tungstated zirconia $\left(\mathrm{WO}_{\mathrm{x}} / \mathrm{ZrO}_{2}\right)$ are common superacid solid catalysts exhibiting super acid strength [12-14]. The catalytic activity of metal oxide acid catalysts is typically low; hence to achieve a higher biodiesel yield, the reaction requires extreme operation conditions, e.g., a temperature higher than $100^{\circ} \mathrm{C}$. However, ferric sulfate $\left(\mathrm{Fe}_{2}\left(\mathrm{SO}_{4}\right)_{3}\right)$ metal oxide acid catalyst shows a good activity for esterification [15].

Multi-metal oxide/supported metal oxide: A multi-metal oxide or supported metal oxide catalyst is synthesized from anchoring of metal or metal oxide onto a support material which increases the surface area and stability of the catalyst. Support materials are metal oxides (usually silica $\left(\mathrm{SiO}_{2}\right)$ and alumina $\left(\mathrm{Al}_{2} \mathrm{O}_{3}\right)$ ) and carbon-based materials.

Generally, feedstocks for esterification contain high FFA content. Use of support materials can create a high surface/volume ratio contributing to an increase in efficiency of catalyst and accessibility of methanol to the TG or FFA. Selected multimetal oxides catalyze esterification based on various feedstocks are shown in Table 3. Titanium oxide sulfate $\left(\mathrm{Ti}\left(\mathrm{SO}_{4}\right) \mathrm{O}\right)$ nano-catalyst is synthesized by impregnating sulfated group into titanium dioxide nanoparticles $\left(\mathrm{TiO}_{2}-\mathrm{NPs}\right)$, an alternative catalyst for esterification. $\mathrm{Ti}\left(\mathrm{SO}_{4}\right) \mathrm{O}$ is one of the superacid solid catalysts with high activity as well as stability [16]. Another novel catalyst, organosulfonic acid-functionalized montmorillonite-MMT $\left(\mathrm{HSO}_{3}-\right.$ MMT), is used as an acid catalyst for both esterification and transesterification of high FFA feedstocks to achieve $100 \%$ biodiesel yield [17]. Furthermore, to meet the target of low cost and environmental friendliness, sulfonated carbon gel (SCG) is selected and prepared from glycerol and concentrated sulfuric acid. This catalyst exhibits a high biodiesel yield 
Table 3 Selected metal oxide acid catalysts (mono-metal oxide, multi-metal oxide, and active site doped metal oxide) for esterification/transesterification and their optimal conditions.

\begin{tabular}{|c|c|c|c|c|c|c|c|c|c|}
\hline Feedstock & Catalyst & $\begin{array}{c}\text { Catalyst } \\
\text { loading (wt.\%) }\end{array}$ & $\begin{array}{l}\text { Type of } \\
\text { alcohol }\end{array}$ & $\begin{array}{l}\mathrm{A} / \mathrm{O} \text { molar } \\
\text { ratio }\end{array}$ & $\begin{array}{c}\mathrm{T} \\
\left({ }^{\circ} \mathrm{C}\right)\end{array}$ & $\begin{array}{l}\text { Time } \\
\text { (h) }\end{array}$ & $\begin{array}{c}\text { Ester } \\
\text { yield (\%) }\end{array}$ & $\begin{array}{c}\text { Oil conversion } \\
(\%)\end{array}$ & Ref. \\
\hline \multicolumn{10}{|l|}{ Mono-metal oxide } \\
\hline WCO & $\mathrm{Fe}_{2}\left(\mathrm{SO}_{4}\right)_{3}$ & 2 & Methanol & $10: 1$ & 95 & 4 & - & 97.2 & {$[15]$} \\
\hline PKO & $\mathrm{SO}_{4}^{2-} / \mathrm{SnO}_{2}$ & 3 & Methanol & $6: 1$ & 200 & 4 & 95.4 & 90.3 & {$[12]$} \\
\hline Crude PKO & $\mathrm{SO}_{4}^{2-} / \mathrm{ZrO}_{2}$ & 3 & Methanol & $6: 1$ & 200 & 4 & 95.8 & 90.3 & {$[12]$} \\
\hline Oleic acid & $\mathrm{Nb}_{2} \mathrm{O}_{5}$ & 0.1 & Methanol & $10: 1$ & 200 & 0.3 & 68.0 & - & [13] \\
\hline \multicolumn{10}{|c|}{ Multi-metal oxide/supported metal oxide } \\
\hline WCO & $\mathrm{SO}_{4}^{2-} / \mathrm{SnO}_{2}-\mathrm{SiO}_{2}$ & 3 & Methanol & $15: 1$ & 150 & 3 & 92.3 & - & [24] \\
\hline WCO & $\mathrm{Ti}\left(\mathrm{SO}_{4}\right) \mathrm{O}$ & 1.5 & Methanol & $9: 1$ & 75 & 3 & 97.1 & - & [16] \\
\hline WCO & SCG & 5 & Methanol & $22: 1$ & 100 & 3 & 92.3 & - & [18] \\
\hline Waste palm oil & $\mathrm{HSO}_{3}-\mathrm{MMT}$ & 5 & Methanol & $8: 1$ & 120 & 2 & 100 & - & [17] \\
\hline Jatropha oil & HPA/AC & 3.5 & Methanol & $25: 1$ & 65 & 0.67 & 91.0 & - & [19] \\
\hline Crude Jatropha oil & TPA/Al & 25 & Methanol & $19: 1$ & 65 & 0.83 & 84.0 & - & {$[21]$} \\
\hline \multicolumn{10}{|c|}{ Active site doped metal oxide/mixed metal oxide (MMO) } \\
\hline WCO & $\mathrm{SO}_{4}^{2-} / \mathrm{Fe}-\mathrm{Al}-\mathrm{TiO}_{2}$ & 3 & Methanol & $10: 1$ & 90 & 2.5 & 96.0 & - & {$[22]$} \\
\hline PFAD* & $\mathrm{SO}_{3} \mathrm{H}-\mathrm{CuO}-\mathrm{ZnO}$ & 1.5 & Methanol & $9: 1$ & 100 & 1.5 & 96.1 & - & [23] \\
\hline WCO & $\mathrm{SO}_{4}^{2-} / \mathrm{Mg}-\mathrm{Al}-\mathrm{Al}_{2} \mathrm{O}_{3}$ & 4 & Methanol & $9: 1$ & 95 & 5 & 98.5 & - & {$[25]$} \\
\hline
\end{tabular}

A/O molar ratio: alcohol to oil molar ratio; T: temperature; * PFAD: palm fatty acid distillate.

and can maintain a more than $90 \%$ yield for two consecutive cycles [18].

Implementation of a novel catalyst in an intensified reactor to enhance the biodiesel production process could further improve the reaction performance. Badday [19] prepared a heteropolyacids supported metal oxide on activated carbon (HPA/AC) for ultrasound-assisted biodiesel production. The highlight of this research was to decrease reaction temperature and reaction time to meet the low energy consumption requirement. The functionalized sulfonated group on activated carbon derived from coffee residue was also used to catalyze the esterification of caprylic acid for biodiesel production [20]. Moreover, the gamma-alumina $\left(\gamma-\mathrm{Al}_{2} \mathrm{O}_{3}\right)$ supported tungstophosphoric acid (TPA) catalyst was used instead of HPA/AC. The result showed that the highest ester yield of $84 \%$ was achieved under the optimal conditions. However, this catalyst required a lower methanol-to-oil molar ratio and could be reused for 3 cycles [21].

Active site doped metal oxide/mixed metal oxide (MMO): An active site doped metal oxide is the impregnation of a metal or metal oxide on a multimetal oxide for enhancement of catalytic activity or stability. Various active site doped metal oxide acid catalysts and their optimal conditions for esterification are listed in Table 3. A novel magnetic $\mathrm{SO}_{4}^{2-} / \mathrm{Fe}$ $\mathrm{Al}-\mathrm{TiO}_{2}$ solid acid catalyst was a good example of an active site doped metal oxide. It consists of $\mathrm{TiO}_{2}$ (rutile and anatase phases) acting as a support. $\mathrm{Al}_{2}\left(\mathrm{SO}_{4}\right)_{3}$ was applied to increase the highly porous second shell, while hematite nanoparticles were added for the magnetic characteristics and the sulfation reaction as the last preparation step to introduce the Brønsted acidity. $\mathrm{SO}_{4}^{2-} / \mathrm{Fe}-\mathrm{Al}_{-}-\mathrm{TiO}_{2}$ showed high catalytic efficiency and excellent stability due to the incorporation of the aforementioned functional species [22]. The synthesis of a mesoporous $\mathrm{CuO}-\mathrm{ZnO}$ mixed metal oxide nanocrystalline catalyst was also found to increase the surface area of the catalyst as well as its stability [23].

Cation resin-supported catalyst: Cation resin is a heterogeneous catalyst that has proven to be effective in esterification. Examples of commercial cation resin catalysts are Relite CFS, Purolite CT275, Dowex, EBD-100, Amberlyst 15, Nafion-NR50, and poly(vinyl alcohol) sulfosuccinic acid. Usually, the cation resin-supported catalyst is recognized by the chemical industry in terms of its stability and reusability. Although the fundamental property of a cation resin is an acid resin, the form of a catalyst is a solid structure which can be referred to as noncorrosive characteristics. Styrene-divinylbenzene (ST-DVB), a macroporous type of a strong acid resin based on the polymer of styrene (ST) cross-linked with divinylbenzene (DVB), is a general-purpose resin for transesterification. Fu et al [26] reported a biodiesel yield of $97.8 \%$ when using: rapeseed oil with oleic acid as a feedstock, $10 \mathrm{wt} \%$ STDVB resin, methanol-to-oil molar ratio of 10:1, and temperature of $70^{\circ} \mathrm{C}$ for $3 \mathrm{~h}$. The biodiesel yield was slightly decreased with the modification of $\mathrm{FeCl}_{3}$-on the ST-DVB resin. However, $\mathrm{FeCl}_{3}$-modified ST-DVB 
is suitable for WCO with high FFA or high moisture content. In addition, this catalyst can be easily separated from the biodiesel product and reused as a spent catalyst several times [27]. Another favored cation resin for esterification is an Amberlyst-type ion. Amberlyst 45 is one of the resins used for esterification with minimization of soap formation from saponification. This catalyst can be used with high FFA oils and hydrated ethanol with minimization of catalyst deactivation [28].

\section{Biodiesel production using base catalyst}

Base catalysts show excellent catalytic activity for transesterification with lesser corrosion problems than the acid catalysts [4]. However, the base catalysts are extremely sensitive to high FFA and water content in feedstocks causing generation of undesirable reactions such as saponification and hydrolysis. Therefore, the feedstock of biodiesel production via transesterification should specify the FFA content of lower than $2 \%$ [29].

\section{Homogeneous catalyst}

Alkaline catalyst: A strong base catalyst (especially sodium hydroxide, potassium hydroxide, and sodium methoxide $\left.\left(\mathrm{CH}_{3} \mathrm{ONa}\right)\right)$ is the major catalyst used for biodiesel production as shown in Table 4. Compared with acid-catalyzed transesterification, base-catalyzed transesterification is often operated at milder conditions resulting in lower energy consumption. Moreover, using an intensified multifunctional reactor, such as ultrasound-assisted reactor, microwave reactor, and microchannel reactor; and operating with co-solvent addition are promising alternatives to enhance the production performance and reduce the operation cost [30-33].

Ionic liquid catalyst: An ionic liquid (IL) is a good catalyst for transesterification. Tetrabutylphosphonium carboxylate ILs ([P4444][CA]) were successfully used in a one-pot transesterification of wet Chlorella vulgaris microalgae to produce FAME [38]. The process could avoid the drying and lipid extrac- tion steps. A biodiesel yield of $98.0 \%$ was obtained when using biomass containing $40 \mathrm{wt} . \%$ water under the optimized conditions: IL:microalgae mass ratio of $8: 1$, water content of $40.6 \%$, reaction temperature of $102.4{ }^{\circ} \mathrm{C}$, and reaction time of $4.6 \mathrm{~h}$. The major problems of this process were the high cost of the IL and the use of excessive methanol.

\section{Heterogeneous catalyst}

Heterogeneous base catalysts are superior for biodiesel production because of their high activity, less corrosion, easy separation, and good recovery. The common solid heterogeneous base catalysts can be divided into 4 types: mono-metal oxide, multi-metal oxide/supported metal oxide, active site doped metal oxide/mixed metal oxide (MMO), and anion resin-supported catalysts.

Mono-metal oxide: For the mono-metal oxide catalysts, the alkaline-earth oxide and transition metal oxide have gained much attention in the biodiesel production application as expressed in Table 5. Recently, the alkaline-earth oxide, especially $\mathrm{CaO}$, is a remarkable solid base catalyst that can be prepared from natural raw materials such as animal bones, eggshells, and sea sand [39-43]. This mono-metal oxide catalyst is promising for transesterification in continuous operations. Moreover, the combined catalyst with ultrasound-assisted reactor could enhance the biodiesel production efficiency due to the generation of cavitation which, subsequently, improved the simultaneous mixing [44-46]. However, the water content in the feedstocks might deactivate its catalytic activity as well as produce an emulsion phase via saponification [47].

Multi-metal oxide/supported metal oxide: The preparation methods of multi-metal oxide base and multi-metal oxide acid catalysts are similar. The multi-metal oxide has various types of support including metal oxide, zeolite, and activated carbon. The highest catalytic activity shown in Table 5 was $98.7 \%$ derived from transesterification of WCO

Table 4 Various homogeneous base catalysts for transesterification and their optimal conditions.

\begin{tabular}{lcccccccc}
\hline Feedstock & Catalyst & $\begin{array}{c}\text { Catalyst } \\
\text { loading (wt.\%) }\end{array}$ & $\begin{array}{c}\text { Type of } \\
\text { alcohol }\end{array}$ & $\begin{array}{c}\text { A/O molar } \\
\text { ratio }\end{array}$ & $\begin{array}{c}\mathrm{T} \\
\left({ }^{\circ} \mathrm{C}\right)\end{array}$ & $\begin{array}{c}\text { Time } \\
(\mathrm{h})\end{array}$ & $\begin{array}{c}\text { Ester } \\
\text { yield }(\%)\end{array}$ & $\begin{array}{c}\text { Ref. } \\
\text { Pork-lard }\end{array}$ \\
Roselle oil & $\mathrm{KOH}$ & 2 & Methanol & $10: 1$ & 60 & 2 & 98.2 & {$[34]$} \\
Sesamum indicum L. seed oil & $\mathrm{KOH}$ & 1.5 & Methanol & $8: 1$ & 60 & 1 & 99.4 & {$[35]$} \\
Castor oil & $\mathrm{CH}_{3} \mathrm{Ona}$ & 0.75 & Methanol & $6: 1$ & 50 & 0.5 & 87.8 & {$[36]$} \\
\hline
\end{tabular}

A/O molar ratio: alcohol to oil molar ratio; T: temperature. 
Table 5 Various mono-metal oxide, multi-metal oxide, and active site doped metal oxide base catalysts for transesterification and their optimal conditions.

\begin{tabular}{|c|c|c|c|c|c|c|c|c|c|}
\hline Feedstock & Catalyst & $\begin{array}{c}\text { Catalyst } \\
\text { loading (wt.\%) }\end{array}$ & $\begin{array}{l}\text { Type of } \\
\text { alcohol }\end{array}$ & $\begin{array}{l}\mathrm{A} / \mathrm{O} \text { molar } \\
\text { ratio }\end{array}$ & $\begin{array}{c}\mathrm{T} \\
\left({ }^{\circ} \mathrm{C}\right)\end{array}$ & $\begin{array}{l}\text { Time } \\
\text { (h) }\end{array}$ & $\begin{array}{c}\text { Ester } \\
\text { yield (\%) }\end{array}$ & $\begin{array}{l}\text { Oil conversion } \\
(\%)\end{array}$ & Ref. \\
\hline \multicolumn{10}{|c|}{ Mono-metal oxide } \\
\hline WCO & $\mathrm{CaO}$ & 1 & Methanol & $8: 1$ & 50 & 1.5 & 96.0 & - & [55] \\
\hline Soybean oil & $\mathrm{CaO}$ - sea sand & 7.5 & Methanol & $12: 1$ & 60 & 6 & 97.5 & - & [39] \\
\hline Soybean oil & $\mathrm{CaO}$ - eggshell & 7 & Methanol & $10: 1$ & 57.5 & 3 & 93.0 & - & [40] \\
\hline WCO & $\mathrm{CaO}$ - chicken and fishbone & $1.98 \mathrm{w} / \mathrm{v} . \%$ & Methanol & $10: 1$ & 65 & 1.5 & 89.5 & - & [41] \\
\hline \multicolumn{10}{|c|}{ Multi-metal oxide/supported metal oxide } \\
\hline Sunflower oil & $\mathrm{Ca} / \mathrm{Fe}_{3} \mathrm{O}_{4} @ \mathrm{SiO}_{2}$ & 8 & Methanol & $15: 1$ & 65 & 5 & 97.0 & - & [56] \\
\hline Sunflower oil & $\mathrm{CaO} / \gamma-\mathrm{Al}_{2} \mathrm{O}_{3}$ & 0.5 & Methanol & $12: 1$ & 60 & 5 & - & 94.3 & [57] \\
\hline WCO & $\mathrm{SrO} / \mathrm{C}$ & 7.1 & Methanol & $6: 1$ & 46 & 1 & 98.5 & - & [58] \\
\hline WCO & $\mathrm{TiO}_{2} / \mathrm{RGO}$ & 1.5 & Methanol & $12: 1$ & 65 & 3 & - & 98.0 & [59] \\
\hline WCO & $\mathrm{Na}_{2} \mathrm{O} / \mathrm{CNTs}$ & 3 & Methanol & $20: 1$ & 65 & 3 & 97.0 & - & {$[60]$} \\
\hline WCO & $\mathrm{Mg} /$ clinoptilolite & 4 & Methanol & $16: 1$ & 70 & 2.5 & 98.7 & - & [48] \\
\hline \multicolumn{10}{|c|}{ Active site doped metal oxide/mixed metal oxide (MMO) } \\
\hline WEO & $\mathrm{CaO} @ \mathrm{MgO}$ & 4.57 & Methanol & $16.7: 1$ & 69.4 & 7.1 & 98.3 & - & [61] \\
\hline Palm oil & $\begin{array}{c}\mathrm{Ca}-\mathrm{Ce}-\mathrm{Zn} / \mathrm{Al}_{2} \mathrm{O}_{3} \\
\left.\text { (Ca:Ce:Zn:Al } \mathrm{O}_{3}=5: 4: 1: 1\right)\end{array}$ & 8.19 & Methanol & $18.5: 1$ & 66.1 & 3 & 99.4 & - & [52] \\
\hline WCO & Ce-doped MCM-41 & 5 & Methanol & $9: 1$ & 70 & 6 & 94.3 & - & [53] \\
\hline WCO & $\mathrm{Ni} / \mathrm{CaO}$ & 1 & Methanol & $16: 1$ & 65 & 2 & 100 & - & [62] \\
\hline WCO & $\mathrm{Na} / \mathrm{CaO}$ & 3 & Methanol & $6: 1$ & 60 & 3.5 & 83.6 & - & [54] \\
\hline
\end{tabular}

A/O molar ratio: alcohol to oil molar ratio; T: temperature.

and methanol using $\mathrm{Mg} /$ clinoptilolite under catalyst loading of $4 \mathrm{wt} . \%$, methanol-to-oil molar ratio of $16: 1$, and $70^{\circ} \mathrm{C}$ for $2.5 \mathrm{~h}$ [48]. Magnetic catalyst is an alternative catalyst. It consists of magnetic material which could be simply separated from the reaction mixture by using a magnet [49-51].

Active site doped metal oxide/mixed metal oxide (MMO): The active site doped metal oxide is developed from mono-metal oxide or multi-metal oxide by introducing different metals to improve the catalytic activity and/or stability (Table 5 ). The specific properties of metal can influence the characteristics of catalysts. For instance, the number of catalyst's basic sites was increased by adding calcium (Ca) or calcium oxide (CaO) [52]; cerium (Ce) dopant on the parent metal oxide could decrease the original crystallinity of the support [53]; and mixed metal oxide could enhance the catalyst's surface areas [54].

Anion resin-supported catalyst: Anion resinsupported catalyst is a heterogeneous catalyst which could provide greater catalytic activity and stability than a homogeneous catalyst. This catalyst could be used in the biodiesel production reaction as well as the purification of biodiesel. Therefore, the catalyst is appropriate for the continuous production process. Ren [63] investigated the continuous transesterification of soybean oil with methanol in a fixed-bed reactor. The biodiesel yield of $95.2 \%$ was achieved using an anion-exchange resin D261 under the following condition: methanol-to-oil molar ratio of 9:1, n-hexane/soybean oil weight rate of 0.5 , feed flow rate of $1.2 \mathrm{ml} / \mathrm{min}$, and temperature of $50^{\circ} \mathrm{C}$ with a residence time of $56 \mathrm{~min}$.

\section{Biodiesel production with bifunctional catalyst}

Although base catalysts show high activity for transesterification, their sensitivity to FFA and water content are the major limitations of these catalysts. Moreover, the catalyst could be deactivated and its catalytic activity reduced when used for a long time. Bifunctional catalysts derived from mixed metal oxides are reported to be active for transesterification due to enhancement of the catalytic activity and stability (Table 6). The characteristics of each metal oxide catalyst are different. Therefore, an intensive study of the physical and chemical properties of metal oxides should be further intensively investigated.

\section{MULTIFUNCTIONAL REACTORS FOR ENHANCED BIODIESEL PRODUCTION}

To improve the efficiency and the sustainability for biodiesel production, the troubleshooting of the immiscibility of oil and alcohol together with using a high-activity catalyst is recommended. Our previous research proposed the use of multifunctional reactors to produce biodiesel, which include reactive distillation $[68,69]$, ultrasonic/cavitation rectors $[45,46,70,71]$, microwave reactor $[31,72]$, 
Table 6 Various bifunctional catalysts for transesterification and their optimal conditions.

\begin{tabular}{|c|c|c|c|c|c|c|c|c|c|}
\hline Feedstock & Catalyst & $\begin{array}{c}\text { Catalyst } \\
\text { loading (wt.\%) }\end{array}$ & $\begin{array}{l}\text { Type of } \\
\text { alcohol }\end{array}$ & $\begin{array}{l}\mathrm{A} / \mathrm{O} \text { molar } \\
\text { ratio }\end{array}$ & $\begin{array}{c}\mathrm{T} \\
\left({ }^{\circ} \mathrm{C}\right)\end{array}$ & $\underset{(\mathrm{h})}{\text { Time }}$ & $\begin{array}{c}\text { Ester } \\
\text { yield (\%) }\end{array}$ & $\begin{array}{c}\text { Oil conversion } \\
(\%)\end{array}$ & Ref. \\
\hline WCO & $\mathrm{Fe}_{2} \mathrm{O}_{3}-\mathrm{MnO}-\mathrm{SO}_{4}^{2-} / \mathrm{ZrO}_{2}$ & 3 & Methanol & $20: 1$ & 180 & 4 & 96.5 & - & [64] \\
\hline Palm oil & $\mathrm{La}_{2} \mathrm{O}_{3} / \mathrm{CaO}$ & 10 & Methanol & $12: 1$ & 60 & 6 & 92.3 & & [65] \\
\hline $\begin{array}{l}\text { sunflower oil }+ \\
10 \text { wt. } \% \text { oleic acid }\end{array}$ & MgO/Al-Ce-MCM-41 & 5 & Methanol & 9:1 & 70 & 6 & - & 95.4 & [66] \\
\hline Triglyceride & $\mathrm{Cu}_{\mathrm{n}} \mathrm{O}-\mathrm{B}_{\mathrm{s}} / \mathrm{SBA}-15$ & 5 & Methanol & $10: 1$ & 40 & 2 & $>97.5$ & - & {$[67]$} \\
\hline
\end{tabular}

A/O molar ratio: alcohol to oil molar ratio; T: temperature.

rotating reactor $[73,74]$, food processing reactor $[75,76]$, and plasma reactor $[77,78]$. Based on our knowledge, this section features some potential multifunctional reactors for biodiesel production.

\section{Microchannel reactor}

The highlight of the microchannel reactor is an intimate flow of reactants inside a narrow channel which could significantly increase their mass transfer. A suitable catalyst for the microchannel reactor should be a homogeneous catalyst because a heterogeneous catalyst may generate friction inside the pipe resulting in internal erosion on the channel surface. Elango [37] reported that the maximum biodiesel yield of $94.9 \%$ was obtained when using a methanol-to-castor oil molar ratio of 12:1 with 1.25 $\mathrm{w} / \mathrm{v} \% \mathrm{KOH}$ at $60^{\circ} \mathrm{C}$.

\section{Microwave reactor}

A microwave reactor (MW) reactor is an intensified reactor especially focusing on the changing of heating source from direct electrical heating to microwave irradiation to improve the heating effectiveness. The operation of MW for biodiesel production can utilize both homogeneous [10,31,72] and heterogeneous $[13,43]$ catalysts. Ding $[10]$ reported that the reaction time of biodiesel production using a microwave reactor is much less than those of conventional processes, and up to $44 \%$ of energy can be saved.

\section{Sonochemical reactor/ultrasound-assisted reactor}

A sonochemical reactor/ultrasound-assisted reactor (US) offers high mixing performance derived from ultrasonic irradiation. Cavitation bubbles are generated when ultrasonic jet impinges on the liquid. The collapse of the bubbles disrupts the phase boundary and increases the miscibility of reactants. The mixing performance is dependent on the intensity of ultrasonic irradiation. Therefore, both homogeneous and heterogeneous catalysts can be used in an appropriate design of the US. The highlight of the US-assisted biodiesel production is the reduction of reaction temperature and reaction time, which results in a 1.5-1.7 times lower energy consumption than that of the conventional process $[19,33,44,45,70,71]$.

\section{Rotating disc reactor and rotating tube reactors}

Rotating disc reactor (RDR) and rotating tube reactor (RTR) are based on similar operating principles. The emphasis of these reactors is the application of high-speed rotation to generate a thin liquid film with a high heat-mass transfer. Moreover, the high-speed rotation generates shear forces inside the reactor promoting high mixing performance. Because of the thin-gap requirement limitation of the reactor design, a homogeneous catalyst is more preferable for application in the RDR and the RTR than a heterogeneous catalyst $[73,74,79,80]$.

\section{CONCLUSION}

Biodiesel is an alternative fuel that is considered environmentally clean energy. The biodiesel production process requires a novel catalyst to accelerate the reaction rate. Simultaneously, the immiscibility of reactants and the difficult separation of catalyst are the two feature restrictions to the performance of biodiesel production. Accordingly, the development of catalysts and advanced multifunctional reactors to improve performance and sustainability of biodiesel production is important. The integration of ultrasonic intensification technology with the functionalized acid and base on metal oxide support is a potential process for continuous biodiesel production to achieve the economic and environmental aspects.

Acknowledgements: The authors would like to acknowledge the supports from the "Research Chair Grant" National Science and Technology Development Agency (NSTDA) and e-ASIA joint research program in the field of bioenergy (JST SICORP Grant Number JPMJSC18E2). 


\section{REFERENCES}

1. Prokop T (2002) Personal Communication, Imperial Western Products, 14970 Chandler St., Coachella, CA.

2. Krawczyk T (1996) Biodiesel-alternative fuel makes inroads but hurdles remain. INFORM 7, 801-829.

3. Gerpen JV (2005) Biodiesel processing and production. Fuel Process Technol 86, 1097-1107.

4. Canakci M, Gerpen JV (1999) Biodiesel production via acid catalysis. Trans ASAE 99, 1203-1210.

5. Miao X, Li R, Yao H (2009) Effective acid-catalyzed transesterification for biodiesel production. Energy Convers Manag 50, 2680-2684.

6. Soriano NU, Venditti R, Argyropoulos DS (2009) Biodiesel synthesis via homogeneous Lewis acidcatalyzed transesterification. Fuel 88, 560-565.

7. Ejeromedoghene O (2021) Acid-catalyzed transesterification of palm kernel oil (PKO) to biodiesel. In: Mater Today: Proc National Conference on Recent Advances in Functional Materials, New Delhi.

8. Ngaosuwan K, Mo X, Goodwin JG, Praserthdam P (2010) Reaction kinetics and mechanisms for hydrolysis and transesterification of triglycerides on tungstated zirconia. Top Catal 53, 783-794.

9. Cai D, Xie Y, Li L, Ren J, Lin X, Qiu T (2018) Design and synthesis of novel Brønsted-Lewis acidic ionic liquid and its application in biodiesel production from soapberry oil. Energy Convers Manag 166, 318-327.

10. Ding H, Ye W, Wang Y, Wang X, Li L, Liu D, Gui J, Song C, et al (2018) Process intensification of transesterification for biodiesel production from palm oil: microwave irradiation on transesterification reaction catalyzed by acidic imidazolium ionic liquids. Energy 144, 957-967.

11. Dai Q, Yang Z, Li J, Cao Y, Tang H, Wei X (2021) Zirconium-based MOFs-loaded ionic liquid-catalyzed preparation of biodiesel from jatropha oil. Renew Energy 163, 1588-1594.

12. Jitputti J, Kitiyanan B, Rangsunvigit P, Bunyakiat K, Attanatho L, Jenvanitpanjakul P (2006) Transesterification of crude palm kernel oil and crude coconut oil by different solid catalysts. Chem Eng $J$ 116, 61-66.

13. Junior CARM, AlbuquerqueJuliana CER, Carneiro JSA, Dariva C, Fortuny M, Santos AF, Egues SMS, Ramos ALD (2010) Solid-acid-catalyzed esterification of oleic acid assisted by microwave heating. Ind Eng Chem Res 49, 12135-12139.

14. Ngaosuwan K, Mo X, Goodwin JG, Praserthdam P (2010) Effect of solvent on hydrolysis and transesterification reactions on tungstated zirconia. Appl Catal A Gen 380, 81-86.

15. Wang Y, Ou S, Liu P, Xue F, Tang S (2006) Comparison of two different processes to synthesize biodiesel by waste cooking oil. J Mol Catal A Chem 252, 107-112.

16. Gardy J, Hassanpour A, Lai X, Ahmed MH (2016)
Synthesis of $\mathrm{Ti}\left(\mathrm{SO}_{4}\right) \mathrm{O}$ solid acid nano-catalyst and its application for biodiesel production from used cooking oil. Appl Catal A Gen 527, 81-95.

17. Silva SM, Peixoto AF, Freire C (2020) Organosulfonic acid functionalized montmorillonites as solid catalysts for (trans) esterification of free fatty acids and (waste) oils. Renew Energy 146, 2416-2429.

18. Shatesh K, Shamsuddin MR, Farabi MSA, Saiman MI, Zainal Z, Taufiq-Yap YH (2020) Production of methyl esters from waste cooking oil and chicken fat oil via simultaneous esterification and transesterification using acid catalyst. Energy Convers Manag 226, ID 113366.

19. Badday AS, Abdullah AZ, Lee K-T (2013) Optimization of biodiesel production process from jatropha oil using supported heteropolyacid catalyst and assisted by ultrasonic energy. Renew Energy 50, 427-432.

20. Ngaosuwan K, Goodwin JG, Prasertdham P (2016) A green sulfonated carbon-based catalyst derived from coffee residue for esterification. Renew Energy 86, 262-269.

21. Badday AS, Abdullah AZ, Lee K-T (2013) Ultrasoundassisted transesterification of crude jatropha oil using alumina-supported heteropolyacid catalyst. Appl Energy 105, 380-388.

22. Gardy J, Osatiashtiani A, Céspedes O, Hassanpour A, Lai X, Lee AF, Wilson K, Rehan M (2018) A magnetically separable $\mathrm{SO}_{4} / \mathrm{Fe}-\mathrm{Al}-\mathrm{TiO}_{2}$ solid acid catalyst for biodiesel production from waste cooking oil. Appl Catal B Environ 234, 268-278.

23. Soltani S, Rashid U, Nehdi IA, Al-Resayes SI (2017) Esterification of palm fatty acid distillate using a sulfonated mesoporous $\mathrm{CuO}-\mathrm{ZnO}$ mixed metal oxide catalyst. Chem Eng Technol 40, 1931-1939.

24. Lam MK, Lee KT, Mohamed AR (2009) Sulfated tin oxide as solid superacid catalyst for transesterification of waste cooking oil: An optimization study. Appl Catal B Environ 93, 134-139.

25. Gardy J, Nourafkan E, Osatiashtiani A, Lee AF, Wilson $\mathrm{K}$, Hassanpour A, Lai X (2019) A core-shell $\mathrm{SO}_{4} / \mathrm{Mg}$ $\mathrm{Al}-\mathrm{Fe}_{3} \mathrm{O}_{4}$ catalyst for biodiesel production. Appl Catal B Environ 259, ID 118093.

26. Fu J, Chen L, Lv P, Yang L, Yuan Z (2015) Free fatty acids esterification for biodiesel production using self-synthesized macroporous cation exchange resin as solid acid catalyst. Fuel 154, 1-8.

27. Ma Y, Wang Q, Sun X, Wu C, Gao Z (2017) Kinetics studies of biodiesel production from waste cooking oil using $\mathrm{FeCl}_{3}$-modified resin as heterogeneous catalyst. Renew Energy 107, 522-530.

28. Cabral NM, Lorenti JP, Plass W, Gallo JMR (2020) Solid acid resin Amberlyst 45 as a catalyst for the transesterification of vegetable oil. Front Chem 8, ID 305.

29. Nurhayati N, Anita S, Amri TA, Linggawati A (2017) Esterification of crude palm oil using $\mathrm{H}_{2} \mathrm{SO}_{4}$ and transesterification using $\mathrm{CaO}$ catalyst derived from 
Anadara granosa. Indones $J$ Chem 17, 309-315.

30. Karmee SK, Chadha A (2005) Preparation of biodiesel from crude oil of Pongamia pinnata. Bioresour Technol 96, 1425-1429.

31. Choedkiatsakul I, Ngaosuwan K, Assabumrungrat S, Mantegna S, Cravotto G (2015) Biodiesel production in a novel continuous flow microwave reactor. Renew Energy 83, 25-29.

32. Mohadesi M, Gouran A, Dehghan Dehnavi A (2021) Biodiesel production using low cost material as high effective catalyst in a microreactor. Energy 219, ID 119671.

33. Ritprasert P, Ngaosuwan K, Assabumrungrata S (2019) Application of co-solvent for improving biodiesel production in an ultrasound-assisted reactor. In: Applied and Advanced Science Exchange (AASE), ETAS/BESM Academic Press, Osaka, Japan.

34. Janchiv A, Oh Y, Choi S (2012) High quality biodiesel production from pork lard by high solvent additive. ScienceAsia 38, 95-101.

35. Nakpong P, Wootthikanokkhan S (2010) Roselle (Hibiscus sabdariffa L.) oil as an alternative feedstock for biodiesel production in Thailand. Fuel 89, 1806-1811.

36. Dawodu FA, Ayodele OO, Bolanle-Ojo T (2014) Biodiesel production from Sesamum indicum L. seed oil: An optimization study. Egypt J Pet 23, 191-199.

37. Elango RK, Sathiasivan K, Muthukumaran C, Thangavelu V, Rajesh M, Tamilarasan K (2019) Transesterification of castor oil for biodiesel production: process optimization and characterization. Microchem $J$ 145, 1162-1168.

38. Malekghasemi S, Kariminia H-R, Plechkova NK, Ward VCA (2021) Direct transesterification of wet microalgae to biodiesel using phosphonium carboxylate ionic liquid catalysts. Biomass Bioenergy 150, ID 106126.

39. Muciño GG, Romero R, Ramírez A, Martínez SL, Baeza-Jiménez R, Natividad R (2014) Biodiesel production from used cooking oil and sea sand as heterogeneous catalyst. Fuel 138, 143-148.

40. Goli J, Sahu O (2018) Development of heterogeneous alkali catalyst from waste chicken eggshell for biodiesel production. Renew Energy 128, 142-154.

41. Tan YH, Abdullah MO, Kansedo J, Mubarak NM, Chan YS, Nolasco-Hipolito C (2019) Biodiesel production from used cooking oil using green solid catalyst derived from calcined fusion waste chicken and fish bones. Renew Energy 139, 696-706.

42. Huang J, Zou Y, Yaseen M, Qu H, He R, Tong Z (2021) Fabrication of hollow cage-like $\mathrm{CaO}$ catalyst for the enhanced biodiesel production via transesterification of soybean oil and methanol. Fuel 290, ID 119799.

43. Lin Y-C, Amesho KTT, Chen C-E, Cheng P-C, Chou F-C (2020) A cleaner process for green biodiesel synthesis from waste cooking oil using recycled waste oyster shells as a sustainable base heterogeneous catalyst under the microwave heating system. Sustain Chem Pharm 17, ID 100310.

44. Sharma A, Kodgire P, Kachhwaha SS (2020) Investigation of ultrasound-assisted $\mathrm{KOH}$ and $\mathrm{CaO}$ catalyzed transesterification for biodiesel production from waste cotton-seed cooking oil: process optimization and conversion rate evaluation. J Clean Prod 259, ID 120982.

45. Poosumas J, Ngaosuwan K, Quitain AT, Assabumrungrat S (2016) Role of ultrasonic irradiation on transesterification of palm oil using calcium oxide as a solid base catalyst. Energy Convers Manag 120, 62-70.

46. Laosuttiwong T, Ngaosuwan K, Kiatkittipong W, Wongsawaeng D, Kim-Lohsoontorn P, Assabumrungrat S (2018) Performance comparison of different cavitation reactors for biodiesel production via transesterification of palm oil. J Clean Prod 205, 1094-1101.

47. Anantapinitwatna A, Ngaosuwan K, Kiatkittipong W, Wongsawaeng D, Anantpinijwatna A, Quitain AT, Assabumrungrat S (2021) Water influence on the kinetics of transesterification using $\mathrm{CaO}$ catalyst to produce biodiesel. Fuel 296, ID 120653.

48. AbuKhadra MR, Basyouny MG, El-Sherbeeny AM, ElMeligy MA, Abd Elgawad AEE (2020) Transesterification of commercial waste cooking oil into biodiesel over innovative alkali trapped zeolite nanocomposite as green and environmental catalysts. Sustain Chem Pharm 17, ID 100289.

49. Liu M, Huang Y, Liu Q, Hu X, Liu Q, Chen H, Dong Y, Zhao Y, et al (2019) Ferric oxide as a support of carbide slag for effective transesterification of triglycerides in soybean oil. Energy Convers Manag 198, ID 111785.

50. Li H, Wang Y, Ma X, Wu Z, Cui P, Lu W, Liu F, Chu H, et al (2020) A novel magnetic CaO-based catalyst synthesis and characterization: enhancing the catalytic activity and stability of $\mathrm{CaO}$ for biodiesel production. Chem Eng J 391, ID 123549.

51. Changmai B, Rano R, Vanlalveni C, Rokhum L (2021) A novel Citrus sinensis peel ash coated magnetic nanoparticles as an easily recoverable solid catalyst for biodiesel production. Fuel 286, ID 119447.

52. Qu T, Niu S, Zhang X, Han K, Lu C (2021) Preparation of calcium modified $\mathrm{Zn}-\mathrm{Ce} / \mathrm{Al}_{2} \mathrm{O}_{3}$ heterogeneous catalyst for biodiesel production through transesterification of palm oil with methanol optimized by response surface methodology. Fuel 284, ID 118986.

53. Dehghani S, Haghighi M (2019) Sono-dispersed $\mathrm{MgO}$ over cerium-doped MCM-41 nanocatalyst for biodiesel production from acidic sunflower oil: surface evolution by altering $\mathrm{Si} / \mathrm{Ce}$ molar ratios. Waste Manage 95, 584-592.

54. Kurniawan E, Nurhayati N (2020) Transesterfication process of waste cooking oil catalyzed by $\mathrm{Na} / \mathrm{CaO}$ derived from blood clam (Anadara Granosa) shells. 
J Sci Data Anal 1, 1-6.

55. Degfie TA, Mamo TT, Mekonnen YS (2019) Optimized biodiesel production from waste cooking oil (WCO) using calcium oxide $(\mathrm{CaO})$ nano-catalyst. Sci Rep 9, ID 18982.

56. Feyzi M, Norouzi L (2016) Preparation and kinetic study of magnetic $\mathrm{Ca} / \mathrm{Fe}_{3} \mathrm{O}_{4} @ \mathrm{SiO}_{2}$ nanocatalysts for biodiesel production. Renew Energy 94, 579-586.

57. Marinković DM, Avramović JM, Stanković MV, Stamenković OS, Jovanović DM, Veljković VB (2017) Synthesis and characterization of spherically-shaped $\mathrm{CaO} / \gamma-\mathrm{Al}_{2} \mathrm{O}_{3}$ catalyst and its application in biodiesel production. Energy Convers Manag 144, 399-413.

58. Tabah B, Nagvenkar AP, Perkas N, Gedanken A (2017) Solar-heated sustainable biodiesel production from waste cooking oil using a sonochemically deposited SrO catalyst on microporous activated carbon. Energy Fuels 31, 6228-6239.

59. Borah MJ, Devi A, Saikia RA, Deka D (2018) Biodiesel production from waste cooking oil catalyzed by in-situ decorated $\mathrm{TiO}_{2}$ on reduced graphene oxide nanocomposite. Energy 158, 881-889.

60. Ibrahim ML, Nik Abdul Khalil NNA, Islam A, Rashid U, Ibrahim SF, Sinar Mashuri SI, Taufiq-Yap $\mathrm{YH}$ (2020) Preparation of $\mathrm{Na}_{2} \mathrm{O}$ supported CNTs nanocatalyst for efficient biodiesel production from waste-oil. Energy Convers Manag 205, ID 112445.

61. Foroutan R, Mohammadi R, Esmaeili H, Mirzaee Bektashi F, Tamjidi S (2020) Transesterification of waste edible oils to biodiesel using calcium oxide@magnesium oxide nanocatalyst. Waste Manage 105, 373-383.

62. Kamaronzaman MFF, Kahar H, Hassan N, Hanafi MF, Sapawe N (2020) Biodiesel production from waste cooking oil using nickel doped onto eggshell catalyst. Mater Today Proc 31, 342-346.

63. Ren $Y$, He B, Yan F, Wang H, Cheng Y, Lin L, Feng Y, Li J (2012) Continuous biodiesel production in a fixed bed reactor packed with anion-exchange resin as heterogeneous catalyst. Bioresour Technol 113, 19-22.

64. Alhassan FH, Rashid U, Taufiq-Yap YH (2015) Synthesis of waste cooking oil-based biodiesel via effectual recyclable bi-functional $\mathrm{Fe}_{2} \mathrm{O}_{3}-\mathrm{MnO}-\mathrm{SO}_{4}^{2-} / \mathrm{ZrO}_{2}$ nanoparticle solid catalyst. Fuel 142, 38-45.

65. Ngaosuwan K, Chaiyariyakul W, Inthong O, Kiatkittipong W, Wongsawaeng D, Assabumrungrat S (2021) $\mathrm{La}_{2} \mathrm{O}_{3} / \mathrm{CaO}$ catalyst derived from eggshells: effects of preparation method and La content on textural properties and catalytic activity for transesterification. Catal Commun 149, ID 106247.

66. Dehghani S, Haghighi M (2019) Sono-dispersion of $\mathrm{MgO}$ over Al-Ce-doped MCM-41 bifunctional nanocatalyst for one-step biodiesel production from acidic oil: influence of ultrasound irradiation and Si/Ce molar ratio. Ultrason Sonochem 54, 142-152.
67. Hu N, Ning P, He L, Guan Q, Shi Y, Miao R (2021) Near-room temperature transesterification over bifunctional $\mathrm{Cu}_{\mathrm{n}} \mathrm{O}-\mathrm{B}_{\mathrm{s}} / \mathrm{SBA}-15$ catalyst for biodiesel production. Renew Energy 170, 1-11.

68. Petchsoongsakul N, Ngaosuwan K, Kiatkittipong W, Aiouache F, Assabumrungrat S (2017) Process design of biodiesel production: hybridization of ester-and transesterification in a single reactive distillation. Energy Convers Manag 153, 493-503.

69. Petchsoongsakul N, Ngaosuwan K, Kiatkittipong W, Wongsawaeng D, Assabumrungrat S (2020) Different water removal methods for facilitating biodiesel production from low-cost waste cooking oil containing high water content in hybridized reactive distillation. Renew Energy 162, 1906-1918.

70. Choedkiatsakul I, Ngaosuwan K, Assabumrungrat S (2013) Application of heterogeneous catalysts for transesterification of refined palm oil in ultrasoundassisted reactor. Fuel Process Technol 111, 22-28.

71. Choedkiatsakul I, Ngaosuwan K, Cravotto G, Assabumrungrat S (2014) Biodiesel production from palm oil using combined mechanical stirred and ultrasonic reactor. Ultrason Sonochem 21, 1585-1591.

72. Choedkiatsakul I, Ngaosuwan K, Assabumrungrat S, Tabasso S, Cravotto G (2015) Integrated flow reactor that combines high-shear mixing and microwave irradiation for biodiesel production. Biomass Bioenergy 77, 186-191.

73. Appamana W, Sukjarern P, Ngaosuwan K, Assabumrungrat $S$ (2019) Intensification of continuous biodiesel production using a spinning disc reactor. $J$ Chem Eng Jpn 52, 545-553.

74. Chanthon N, Ngaosuwan K, Kiatkittipong W, Wongsawaeng D, Appamana W, Quitain AT, Assabumrungrat S (2021) High-efficiency biodiesel production using rotating tube reactor: new insight of operating parameters on hydrodynamic regime and biodiesel yield. Renew Sustain Energy Rev 151, ID 111430.

75. Wongsawaeng D, Ngaosuwan K, Kiatkittipong W, Laosuttiwong T, Chanthon N, Kanjanapaparkul K, Assabumrungrat S (2019) Simple and effective technology for sustainable biodiesel production using high-power household fruit blender. J Clean Prod 237, ID 117842.

76. Kamjam M, Wongjaikham W, Wongsawaeng D, Ngaosuwan K, Kiatkittipong W, Hosemann P, Assabumrungrat S (2021) Continuous biodiesel production based on hand blender technology for sustainable household utilization. J Clean Prod 297, ID 126737.

77. Kongprawes G, Wongsawaeng D, Hosemann P, Ngaosuwan K, Kiatkittipong W, Assabumrungrat S (2021) Improvement of oxidation stability of fatty acid methyl esters derived from soybean oil via partial hydrogenation using dielectric barrier discharge plasma. Int $J$ Energy Res 45, 4519-4533.

78. Wongjaikham W, Kongprawes G, Wongsawaeng D, Ngaosuwan K, Kiatkittipong W, Hosemann P, Ass- 
abumrungrat S (2021) Highly effective microwave plasma application for catalyst-free and low temperature hydrogenation of biodiesel. Fuel 305, ID 121524.

79. Qiu Z, Petera J, Weatherley LR (2012) Biodiesel synthesis in an intensified spinning disk reactor. Chem
Eng $J$ 210, 597-609.

80. Holl RA (2010) Spinning Tube in Tube Reactors and Their Methods of Operation. US Patent 7780927 2B. Available at: https://patents.google. com/patent/US7780927. 